GO INFOTECH: JURNAL ILMIAH STMIK AUB

Vol.24, No.2, Desember 2018

ISSN (p): 1693-590x, ISSN (e): 2686-4711

DOI: $10.36309 /$ goi.v24i2.88

\title{
Aplikasi Pariwisata Jambi Berbasis Android
}

\author{
Ratna Herawati*1, Widyo Ari Utomo ${ }^{2}$, Indah Royana ${ }^{3}$ \\ ${ }^{1}$ Program Studi Sistem Informasi; ${ }^{2}$ Program Studi Sistem Komputer; \\ ${ }^{3}$ Program Studi Sistem Informasi \\ ${ }^{123}$ STMIK AUB Surakarta, Indonesia \\ e-mail: *1ratna.herawati@stmik-aub.ac.id, ${ }^{2}$ widyoari@stmik-aub.ac.id, ${ }^{3}$ indahyana@gmail.com
}

\begin{abstract}
Abstrak
Jambi adalah sebuah provinsi di Indonesia yang terletak di pesisir timur di bagian tengah Pulau Sumatra. Jambi adalah satu dari tiga provinsi di Indonesia yang ibukota-nya bernama sama dengan nama provinsinya, selain Bengkulu dan Gorontalo. Provinsi Jambi memiliki kekayaan yang melimpah, indah dan unik. Termasuk dengan keberadaan 4 taman nasional yaitu Taman Nasional Kerinci Sebelat, Taman Nasional Berbak, Taman Nasional Bukit Tiga Puluh, dan Taman Nasional Bukit Dua Belas yang mempunyai keunikan masingmasing. Disamping itu, beberapa kawasan bagi pencinta petualangan yaitu, Gunung Krinci, Perkebunana Teh Kayu Aro, Harapan Rainforest. Dalam membantu wisatawan untuk mengetahui tempat wisata di Provinsi Jambi, kita perlu membuat Aplikasi Pariwisata Jambi Berbasis Android. Menggunakan Aplikasi Pariwisata Jambi Berbasis Android, wisatawan dapat dengan mudah mencari informasi tentang daerah-daerah wisata yang ada di Provinsi Jambi. Dalam pembangunan aplikasi ini, penulis menggunkan Android Studio 3.13 dan PhpMyAdmin sebagai database yang menunjang kinerja dalam mengolah data. Aplikasi Pariwisata Jambi Berbasis Android dibangun dengan menggunakan metode Waterfall. Teknik pengumpulan data yang digunakan observasi, wawancara dan studi pustaka. Untuk alur data digambarkan dengan UML(Unified Modeling Language).
\end{abstract}

Kata kunci: Android, Aplikasi, Pariwisata

\section{PENDAHULUAN}

Pariwisata adalah berbagai macam kegiatan wisata dan didukung dengan berbagai fasilitas serta layanan yang disediakan oleh masyarakat, pengusaha, pemerintah dan pemerintah daerah. Sektor pariwisata merupakan salah satu sektor andalan kegiatan perekonomian yang berorientasi pada perluasan lapangan kerja dan kesempatan kerja. Sejalan dengan usaha pemerintah dalam mencapai sasaran pembangunan. Pengembangan sektor pariwisata saat ini mendapat perhatian serius karena selain untuk menciptakan lapangan kerja, pembangunan pariwisata mampu mengalakkan kegiatan ekonomi lainnya, termasuk pendapatan daerah dan negara serta penerimaan devisa.

Sistem Informasi Pariwisata di Provinsi Jambi saat ini berbasis web dan android. Untuk sistem informasi pariwisata jambi berbasis web, menampilkan foto wisata, alamat dan keterangan objek wisata, sedangkan untuk sistem informasi pariwisata jambi berbasis android, hanya menampilkan foto dan alamat objek wisata. Informasi yang disediakan dari web dan aplikasi android tidak lengkap dan update. Adanya masalah tersebut, penulis mengembangkaan aplikasi android yang menampilkan berbagai sarana pendukung wisata seperti menampilkan objek wisata, hotel, kuliner dan dapat melihat peta lokasi wisata atau yang sering disebut longitude dan latitude.

Selama ini wisatawan hanya dapat melihat foto wisata, alamat dan keteranagan dari objek wisata yang dituju. Wisatawan tidak dapat melihat informasi berupa peta wisata dan

Received November 12, 2018; Revised November 28, 2018; Accepted December 10, 2018 
sarana pendukung wisata lainnya seperti kuliner, hotel serta lokasi wisata dalam bentuk peta dinamis. Aplikasi android ini sangat membantu dalam memberikan informasi pariwisata khususnya di Provinsi Jambi serta mempermudah wisatawan dalam mencari informasi mengenai objek wisata maupun informasi sarana pendukung wisata seperti kuliner, hotel dan lokasi wisata di Provinsi Jambi.

Berdasarkan permasalahan yang ada, maka penulis membuat judul Aplikasi Pariwisata Jambi Berbasis Android untuk mempermudah wisatawan dalam mencari informasi wisata, kuliner, hotel serta lokasi wisata dalam bentuk peta wisata yang dinamis. Dalam pengembangan sistem, wisatawan dapat menggunakan aplikasi yang memiliki kelebihan baik dari segi kemudahan operasional, kecepatan akses dan kelengkapan dalam memberikan informasi dan sarana pendukung wisata, seperti saat memilih objek wisata akan tampil informasi mengenai objek wisata tersebut serta akan tampil peta lokasi wisata atau yang sering disebut longitude dan latitude, kemudian saat memilih menu hotel wisatawan dapat memilih hotel sesuai keiginan baik dari segi layanan maupun harga hotel serta wisatawan dapat memilih hotel terdekat dari posisi saat ini menggunakan menu dekat saya, selanjutnya wisatawan dapat memilih menu kuliner, didalam menu kuliner wisatawan dapat memilih kuliner sesuai dengan selera, serta akan tampil peta lokasi (longitude dan latitude), selain dari ketiga menu tersebut aplikasi ini juga memberian informasi mengenai wisata, hotel dan kuliner terdekat dengan lokasi wisatawan berada saat ini yaitu dengan memilih menu dekat saya, wisatawan dapat mengetikkan baik wisata, hotel ataupun kuliner kemudian klik button cari maka akan tampil wisata, hotel atau kuliner terdekat.

\section{METODE PENELITIAN}

Berikut merupakan metode-metode yang diguankan dalam penelitian yang dilakukan:

\subsection{Metode Pengumpulan Data}

1. Metode Observasi

Pengamatan (Observasi) merupakan suatu proses yang kompleks, yaitu suatu proses yang tersusun dari berbagai data dimana peneliti mencatat informasi sebagaimana yang mereka saksikan selama penelitian. Penyaksian terhadap peristiwa-peristiwa itu bisa dengan melihat, mendengarkan, merasakan, yang kemudian dicatat se-subyektif mungkin. Peranan pengamat dapat dibedakan berdasarkan hubungan partisipatifnya dengan kelompok yang diamatinya (Sugiyono, 2013).

2. Metode Wawancara

Wawancara adalah bentuk komunikasi langsung antara peneliti dan responden atau pertemuan dua orang untuk bertukar informasi dan ide serta berkomunikasi berlangsung dalam bentuk tanya jawab dalam hubungan tatap muka, sehingga gerak dan mimik responden merupakan pola media yang melengkapi kata-kata secara verbal. Karena itu, wawancara tidak hanya menangkap pemahaman atau ide, tetapi juga dapat menangkap perasaan, pengalaman, emosi, motif yang dimiliki oleh responden yang bersangkutan (Sugiyono, 2013).

3. Metode Studi Pustaka

Studi kepustakaan berkaitan dengan kajian teoritis dan referensi lain yang berkaitan dengan nilai, budaya dan norma yang berkembang pada situasional yang diteliti, selain itu studi keputusan sangat penting dalam melakukan penelitian, hal ini dikarenakan penelitian tidak akan lepas dari literatur-literatur ilmiah. Metode ini digunakan peneliti dalam mendapatkan data pada buku-buku dan jurnal (Sugiyono, 2013).

\subsection{Metode Pengembangan Sistem}

Proses pengembangan sistem menggunakan metode Waterfall mempunyai langkah-langkah sebagai yaitu, analisa, desain, penulisan, pengujian dan penerapan serta pemeliharaan (Pressman, 2012).

GO INFOTECH: JURNAL ILMIAH STMIK AUB Vol. 24, No. 2, Desember 2018 : 81 - 94 


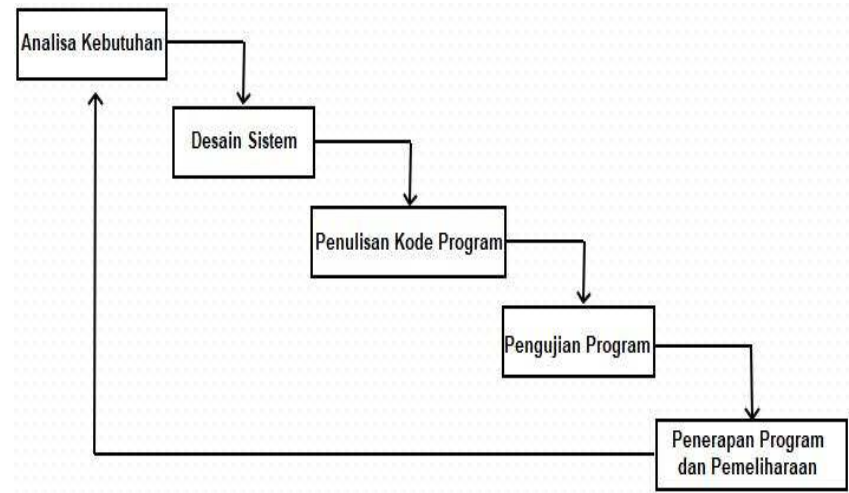

Gambar 1 Metode Waterfall

Adapun tahapan-tahapan yang dilakukan yaitu:

1. Analisa Kebutuhan

Analisa kebutuhan merupakan analisa teradap kebutuhan sistem. Pengumpulan data dalam tahap ini bisa melakukan sebuah penelitian, wawancara atau studi literatur. Sistem analis akan menggali informasi sebanyak-banyaknnya dari user sehingga akan tercipta sebuah sistem komputer yang bisa melakukan tugas-tugas yang diinginkan oleh user tersebut. Tahapan ini akan menghasilkan dokumen user requirment atau bisa dikatakan sebagai data yang berhubungan dengan keinginan user dalam pembuatan sistem. Dokumen ini akan menjadi acuan sistem analis utnuk menerjemahkan kedalam bahasa pemrograman.

2. Desain Sistem

Desain sistem merupakan tahapan dimana dilakukan penuangan pikiran dan perancangan sistem terhadap solusi dan permasalahan yang ada dengan menggunakan perangkat pemodelan sistem seperti diagram hubungan entitas (entity reationship diagram) serta struktur dan bahasan data.

3. Penulisan Kode Program

Penulisan kode program atau coding merupakan penerjemahan design dalam bahasa yang bisa dikenali oleh komputer. Dilakukan oleh programmer yang akan menerjemahkan transaksi yang diminta oleh user. Tahapan ini lah yag merupakan tahapan secara nyata dalam mengerjakan suatu sistem. Dalam artian penggunaan komputer akan dimaksimalkan dalam tahapan ini. Setelah pengkodean selesai maka akan dilakukan testing terhadap sistem yang telah dibuat. Tujuan testing adalah menemukan kesalahan-kesalahan terhadap sistem tersebut dan kemudian bisa diperbaiki.

4. Pengujian Program

Pengujian program merupakan tahapan akhir dimana sistem yang baru diuji kemampuan dan keefektifannya sehingga didapatkan kekurangan dan kelemahan sistem yang kemudian dilakukan pengkajian ulang dan perbaikan terhadap aplikai menjadi lebih baik dan sempurna.

5. Penerapan Program dan Pemeliharaan

Penerapan program dan pemeliharaan merupakan perangkat lunak yang sudah disampaikan kepada pelanggan pasti akan mengalami perubahan. Perubahan tersebut bisa karena mengalami kesalahan karena mengalami kesalahan karena perangkat lunak harus menyesuaiakan dengan lingkungan (periieral atau sistem operasi baru) baru, atau karena pelanggan membutuhkan perkembangan fungsional.

\section{HASIL DAN PEMBAHASAN}

\subsection{Hasil}


Hasil implementasi yang dimaksud merupakan penerapan sistem yang baru yang melalui tahapan uji coba sistem dan program, manual program, manual instalasi, pemeliharaan sistem, serta pembahasan.

\subsubsection{Uji Coba Sistem}

Pada bagian ini menguraikan tentang tahapan-tahapan dalam melakukan pengujian terhadap sistem dan program yang sudah dibuat, sehingga sistem tersebut bebas dari kesalahan agar dapat dilanjutkan pada proses selanjutnya yaitu implementasi sistem dengan menggunkan blackbox testing sebagai metode pengujian sistem.

Tabel 1 Pengujian Blackbox Testing System

\begin{tabular}{|c|c|c|c|c|c|}
\hline No & $\begin{array}{c}\text { Fungsi yang } \\
\text { Diuji }\end{array}$ & $\begin{array}{c}\text { Data } \\
\text { Masukkan }\end{array}$ & $\begin{array}{l}\text { Hasil yang } \\
\text { Diharapkan }\end{array}$ & Pengamatan & Kesimpulan \\
\hline 1 & $\begin{array}{l}\text { Halaman login } \\
\text { admin. }\end{array}$ & $\begin{array}{l}\text { Username } \\
\text { dan } \\
\text { password } \\
\text { salah. }\end{array}$ & $\begin{array}{l}\text { Tidak dapat } \\
\text { masuk pada } \\
\text { halaman home } \\
\text { web admin. }\end{array}$ & Gagal login. & Valid \\
\hline 2 & $\begin{array}{l}\text { Halaman login } \\
\text { admin. }\end{array}$ & $\begin{array}{l}\text { Username } \\
\text { dan } \\
\text { password } \\
\text { benar. }\end{array}$ & $\begin{array}{l}\text { Sistem dapat } \\
\text { masuk pada } \\
\text { halaman hime } \\
\text { web admin. }\end{array}$ & $\begin{array}{l}\text { Berhasil } \\
\text { login. }\end{array}$ & Valid \\
\hline 3 & $\begin{array}{l}\text { Halaman } \\
\text { mengelola data } \\
\text { wisata pada web } \\
\text { admin. }\end{array}$ & $\begin{array}{l}\text { Klik } \\
\text { tombol } \\
\text { tambah } \\
\text { data wisata. }\end{array}$ & $\begin{array}{l}\text { Data wisata } \\
\text { tersimpan pada } \\
\text { database. }\end{array}$ & $\begin{array}{l}\text { Menampilkan } \\
\text { data wisata } \\
\text { pada halaman } \\
\text { mengelola } \\
\text { data wisata. }\end{array}$ & Valid \\
\hline 4 & $\begin{array}{l}\text { Halaman } \\
\text { mengelola data } \\
\text { wisata pada web } \\
\text { admin. }\end{array}$ & $\begin{array}{l}\text { Klik } \\
\text { tombol } \\
\text { detail salah } \\
\text { satu data } \\
\text { wisata. }\end{array}$ & $\begin{array}{l}\text { Dapat } \\
\text { menampilkan } \\
\text { informasi data } \\
\text { wisata secara } \\
\text { detail. }\end{array}$ & $\begin{array}{l}\text { Menampilkan } \\
\text { foto, nama } \\
\text { wisata, } \\
\text { kategori, } \\
\text { alamat, dan } \\
\text { keterangan } \\
\text { wisata. }\end{array}$ & Valid \\
\hline 5 & $\begin{array}{l}\text { Halaman } \\
\text { mengelola data } \\
\text { wisata pada web } \\
\text { admin. }\end{array}$ & $\begin{array}{l}\text { Klik } \\
\text { tombol } \\
\text { edit, lalu } \\
\text { edit data } \\
\text { wisata. }\end{array}$ & $\begin{array}{l}\text { Data wisata ter- } \\
\text { update pada } \\
\text { database. }\end{array}$ & $\begin{array}{l}\text { Data wisata } \\
\text { telah update } \\
\text { dan tampil } \\
\text { dihalaman } \\
\text { mengelola } \\
\text { data wisata. } \\
\end{array}$ & Valid \\
\hline 6 & $\begin{array}{l}\text { Halaman } \\
\text { mengelola data } \\
\text { wisata pada web } \\
\text { admin. }\end{array}$ & $\begin{array}{l}\text { Klik } \\
\text { tombol } \\
\text { hapus. }\end{array}$ & $\begin{array}{l}\text { Data wisata akan } \\
\text { terhapus. }\end{array}$ & $\begin{array}{l}\text { Data wisata } \\
\text { pada halaman } \\
\text { mengelola } \\
\text { data wisata } \\
\text { berhasil } \\
\text { terhapus. }\end{array}$ & Valid \\
\hline 7 & $\begin{array}{l}\text { Halaman } \\
\text { mengelola data } \\
\text { hotel pada web } \\
\text { admin }\end{array}$ & $\begin{array}{l}\text { Klik } \\
\text { tombol } \\
\text { tambah } \\
\text { data hotel. }\end{array}$ & $\begin{array}{l}\text { Data hotel } \\
\text { tersimpan pada } \\
\text { database }\end{array}$ & $\begin{array}{l}\text { Menampilkan } \\
\text { data hotel } \\
\text { pada halaman } \\
\text { mengelola } \\
\text { data hotel. }\end{array}$ & Valid \\
\hline 8 & $\begin{array}{l}\text { Halaman } \\
\text { mengelola data } \\
\text { hotel pada } w e b\end{array}$ & $\begin{array}{l}\text { Klik } \\
\text { tombol } \\
\text { detail salah }\end{array}$ & $\begin{array}{l}\text { Dapat } \\
\text { menampilkan } \\
\text { informasi data }\end{array}$ & $\begin{array}{l}\text { Menampilkan } \\
\text { foto, nama } \\
\text { hotel, }\end{array}$ & Valid \\
\hline
\end{tabular}

GO INFOTECH: JURNAL ILMIAH STMIK AUB Vol. 24, No. 2, Desember 2018： 81 - 94 


\begin{tabular}{|c|c|c|c|c|c|}
\hline No & $\begin{array}{c}\text { Fungsi yang } \\
\text { Diuji }\end{array}$ & $\begin{array}{c}\text { Data } \\
\text { Masukkan }\end{array}$ & $\begin{array}{l}\text { Hasil yang } \\
\text { Diharapkan }\end{array}$ & Pengamatan & Kesimpulan \\
\hline & admin. & $\begin{array}{l}\text { satu data } \\
\text { hotel. }\end{array}$ & $\begin{array}{l}\text { hotel secara } \\
\text { detail. }\end{array}$ & $\begin{array}{l}\text { kategori, } \\
\text { alamat, dan } \\
\text { keterangan } \\
\text { hotel. }\end{array}$ & \\
\hline 9 & $\begin{array}{l}\text { Halaman } \\
\text { mengelola data } \\
\text { hotel pada web } \\
\text { admin. }\end{array}$ & $\begin{array}{l}\text { Klik } \\
\text { tombol } \\
\text { edit, lalu } \\
\text { edit data } \\
\text { hotel. }\end{array}$ & $\begin{array}{l}\text { Data hotel ter- } \\
\text { update pada } \\
\text { database. }\end{array}$ & $\begin{array}{l}\text { Data hotel } \\
\text { telah update } \\
\text { dan tampil } \\
\text { dihalaman } \\
\text { mengelola } \\
\text { data hotel. }\end{array}$ & Valid \\
\hline 10 & $\begin{array}{l}\text { Halaman } \\
\text { mengelola data } \\
\text { hotel pada web } \\
\text { admin. }\end{array}$ & $\begin{array}{l}\text { Klik } \\
\text { tombol } \\
\text { hapus. }\end{array}$ & $\begin{array}{l}\text { Data hotel akan } \\
\text { terhapus. }\end{array}$ & $\begin{array}{l}\text { Data hotel } \\
\text { pada halaman } \\
\text { mengelola } \\
\text { data hotel } \\
\text { berhasil } \\
\text { terhapus. }\end{array}$ & Valid \\
\hline 11 & $\begin{array}{l}\text { Halaman } \\
\text { mengelola data } \\
\text { kuliner pada web } \\
\text { admin. }\end{array}$ & $\begin{array}{l}\text { Klik } \\
\text { tombol } \\
\text { tambah } \\
\text { data } \\
\text { kuliner. }\end{array}$ & $\begin{array}{l}\text { Data kuliner } \\
\text { tersimpan pada } \\
\text { database }\end{array}$ & $\begin{array}{l}\text { Menampilkan } \\
\text { data kuliner } \\
\text { pada halaman } \\
\text { mengelola } \\
\text { data kuliner. }\end{array}$ & Valid \\
\hline 12 & $\begin{array}{l}\text { Halaman } \\
\text { mengelola data } \\
\text { kuliner pada web } \\
\text { admin. }\end{array}$ & $\begin{array}{l}\text { Klik } \\
\text { tombol } \\
\text { detail salah } \\
\text { satu data } \\
\text { kuliner. }\end{array}$ & $\begin{array}{l}\text { Dapat } \\
\text { menampilkan } \\
\text { informasi data } \\
\text { kuliner secara } \\
\text { detail }\end{array}$ & $\begin{array}{l}\text { Menampilkan } \\
\text { foto, nama } \\
\text { kuliner, } \\
\text { kategori, } \\
\text { alamat, dan } \\
\text { keterangan } \\
\text { kuliner. }\end{array}$ & Valid \\
\hline 13 & $\begin{array}{l}\text { Halaman } \\
\text { mengelola data } \\
\text { kuliner pada web } \\
\text { admin. }\end{array}$ & $\begin{array}{l}\text { Klik } \\
\text { tombol } \\
\text { edit, lalu } \\
\text { edit data } \\
\text { kuliner. }\end{array}$ & $\begin{array}{l}\text { Data kuliner ter- } \\
\text { update pada } \\
\text { database. }\end{array}$ & $\begin{array}{l}\text { Data kuliner } \\
\text { telah update } \\
\text { dan tampil } \\
\text { dihalaman } \\
\text { mengelola } \\
\text { data kuliner. }\end{array}$ & Valid \\
\hline 14 & $\begin{array}{l}\text { Halaman } \\
\text { mengelola data } \\
\text { kuliner pada web } \\
\text { admin. }\end{array}$ & $\begin{array}{l}\text { Klik } \\
\text { tombol } \\
\text { hapus. }\end{array}$ & $\begin{array}{l}\text { Data kuliner } \\
\text { akan terhapus. }\end{array}$ & $\begin{array}{l}\text { Data kuliner } \\
\text { pada halaman } \\
\text { mengelola } \\
\text { data kuliner } \\
\text { berhasil } \\
\text { terhapus. }\end{array}$ & Valid \\
\hline 15 & $\begin{array}{l}\text { Halaman utama } \\
\text { pada } w e b \text { admin. }\end{array}$ & $\begin{array}{l}\text { Klik } \\
\text { tombol } \\
\text { keluar. }\end{array}$ & $\begin{array}{l}\text { Dapat keluat dari } \\
\text { web admin. }\end{array}$ & $\begin{array}{l}\text { Berhasil } \\
\text { keluar dat web } \\
\text { admin. }\end{array}$ & Valid \\
\hline 16 & $\begin{array}{l}\text { Halaman utama } \\
\text { Aplikasi Wisata } \\
\text { Jambi. }\end{array}$ & $\begin{array}{l}\text { Klik } \\
\text { tombol } \\
\text { wisata }\end{array}$ & $\begin{array}{l}\text { Dapat } \\
\text { menampilakan } \\
\text { pilih kategori dan } \\
\text { menampilkan list } \\
\text { wisata. }\end{array}$ & $\begin{array}{l}\text { Menampilkan } \\
\text { informasi } \\
\text { wisata dan } \\
\text { peta wisata } \\
\text { beserta rute } \\
\text { wisata yang }\end{array}$ & Valid \\
\hline
\end{tabular}




\begin{tabular}{|l|l|l|l|l|l|}
\hline No & \multicolumn{1}{|c|}{$\begin{array}{c}\text { Fungsi yang } \\
\text { Diuji }\end{array}$} & \multicolumn{1}{|c|}{$\begin{array}{c}\text { Data } \\
\text { Masukkan }\end{array}$} & \multicolumn{1}{|c|}{$\begin{array}{c}\text { Hasil yang } \\
\text { Diharapkan }\end{array}$} & \multicolumn{1}{|c|}{ Pengamatan } & Kesimpulan \\
\hline 17 & $\begin{array}{l}\text { Halaman utama } \\
\text { Aplikasi Wisata } \\
\text { Jambi. }\end{array}$ & $\begin{array}{l}\text { Klik } \\
\text { tombol } \\
\text { hotel. }\end{array}$ & $\begin{array}{l}\text { Dapat } \\
\text { menampilkan list } \\
\text { hotel. }\end{array}$ & $\begin{array}{l}\text { Menampilkan } \\
\text { peta lokasi } \\
\text { hotel dan rute } \\
\text { yang harus di } \\
\text { tempuh. }\end{array}$ & Valid \\
\hline 18 & $\begin{array}{l}\text { Halaman utama } \\
\text { Aplikasi Wisata } \\
\text { Jambi. }\end{array}$ & $\begin{array}{l}\text { Klik } \\
\text { tombol } \\
\text { kuliner }\end{array}$ & $\begin{array}{l}\text { Dapat } \\
\text { menampilkan list } \\
\text { kuliner }\end{array}$ & $\begin{array}{l}\text { Menampilkan } \\
\text { peta lokasi } \\
\text { kuliner dan } \\
\text { rute yang } \\
\text { harus } \\
\text { ditempuh. }\end{array}$ & Valid \\
\hline 19 & $\begin{array}{l}\text { Halaman utama } \\
\text { Aplikasi Wisata } \\
\text { Jambi. }\end{array}$ & $\begin{array}{l}\text { Klik } \\
\text { tombol } \\
\text { info. }\end{array}$ & $\begin{array}{l}\text { Dapat } \\
\text { menampilkan } \\
\text { informasi } \\
\text { mengenai } \\
\text { manfaat aplikasi. }\end{array}$ & $\begin{array}{l}\text { Menampilkan } \\
\text { informasi } \\
\text { tentang } \\
\text { manfaat } \\
\text { aplikasi. }\end{array}$ & Valid \\
\hline 20 & $\begin{array}{l}\text { Halaman utama } \\
\text { Aplikasi Wisata } \\
\text { Jambi. }\end{array}$ & $\begin{array}{l}\text { Kliktombol } \\
\text { tentang. }\end{array}$ & $\begin{array}{l}\text { Dapat } \\
\text { menampilkan } \\
\text { informasi profil } \\
\text { pembuat aplikasi }\end{array}$ & $\begin{array}{l}\text { Menampilkan } \\
\text { informasi } \\
\text { profil } \\
\text { pembuat } \\
\text { aplikasi }\end{array}$ & Valid \\
\hline
\end{tabular}

\subsubsection{Manual Program}

Manual program ini akan dijelaskan bagaimana cara penggunakan sistem yang telah dibuat. Sistem yang dibuat yaitu berbasis Android dan Web. Hak akses Web hanya dapat diakses oleh Admin pengelola. Berikut penjelasan dari fitur atau menu yang telah dibuat:

a. User

1. Tampilan Utama User

Tampilan Utama User dapat dilihat pada gambar 2 sebagai berikut:

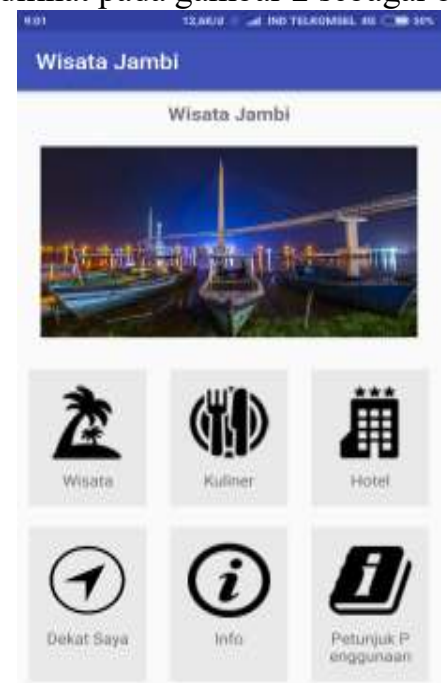

Gambar 2 Tampilan Utama User

Gambar 2 tampilan utama user berisikan button atau tombol pilihan seperti button wisata, kuliner dan hotel serta button informasi dan tentang yaitu berisikan informasi mengenai aplikasi tersebut.

2. Tampilan Pilih Kategori Wisata 
Tampilan Pilih Kategorri Wisata dapat dilihat pada gambar 3 sebagai berikut:

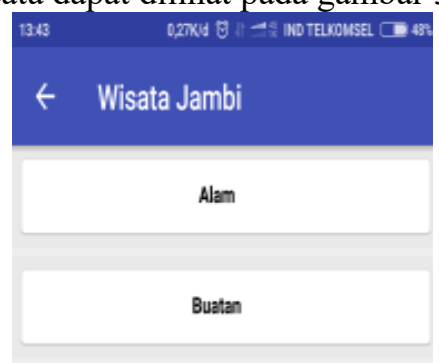

Gambar 3 Tampilan Pilih Kategori

Gambar 3 Tampilan Pilih Kategori merupakan pilihan kategori wisata yaitu wisata alam dan wisata buatan, sehingga user dapat memilih kategori wisata yang akan dikunjungi.

3. Tampilan Menu Wisata

a) Tampilan List Wisata

Tampilan list Wisata dapat dilihat pada gambar 4 sebagai berikut:

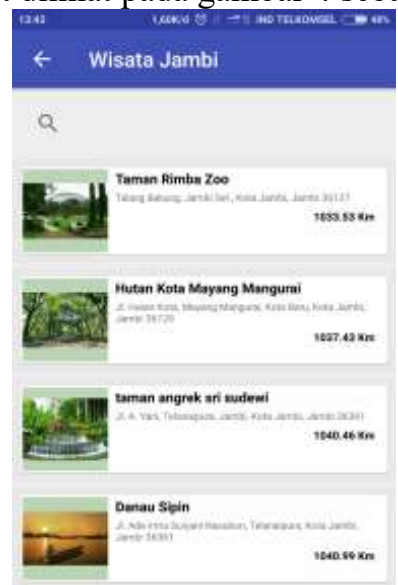

Gambar 4 Tampilan List wisata

Gambar 4 merupakan Tampilan List wisata dimana user dapat memilih wisata mana yang akan dituju.

b) Tampilan Peta Lokasi Wisata

Tampilan Peta Lokasi Wisata dapat dilihat pada gambar 5 sebagai berikut:

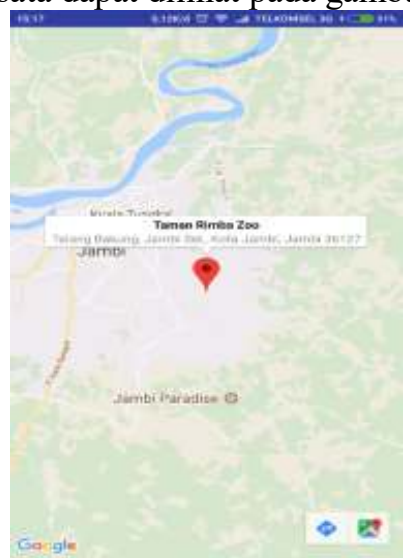

Gambar 5 Peta Lokasi Wisata 
Gambar 5 merupakan Peta Lokasi Wisata yang dituju user, dari peta tersebut user dapat melihat rute mana yang harus tempuh, selain itu user juga dapat mengetahui waktu yang dibutuhkan untuk sampai ketujuan wisata.

4. Tampilan List Kuliner

Tampilan List Kuliner dapat dilihat pada gambar 6 sebagai berikut:

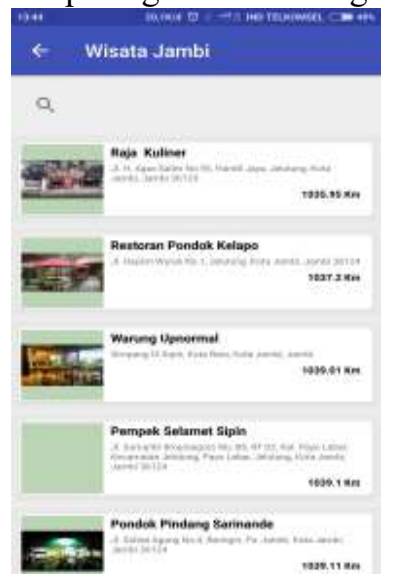

Gambar 6 Tampilan List Kuliner

Gambar 6 merupakan Tampilan List kuliner dimana user dapat memilih kuliner yang akan dituju.

a) Tampilan Lokasi Kuliner

Tampilan Lokasi Kuliner dapat dilihat pada gambar 7 sebagai berikut:

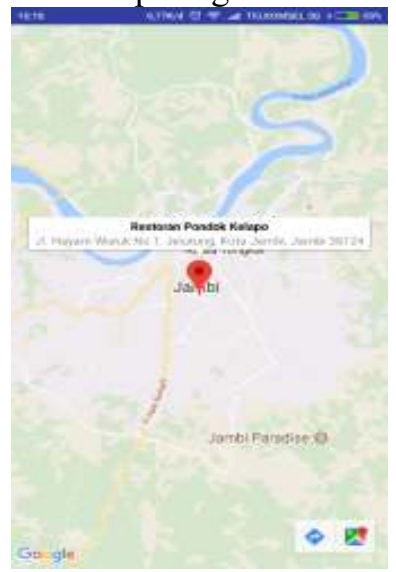

Gambar 7 Tampilan Lokasi Kuliner

Gambar 7 merupakan Tampilan Lokasi Kuliner yang dituju user, dari peta tersebut user dapat melihat rute mana yang harus tempuh, selain itu user juga dapat mengetahui waktu yang dibutuhkan untuk sampai ketujuan kuliner.

5. Tampilan List Hotel

Tampilan List Hotel dapat dilihat pada Gambar 4.7 sebagai berikut: 


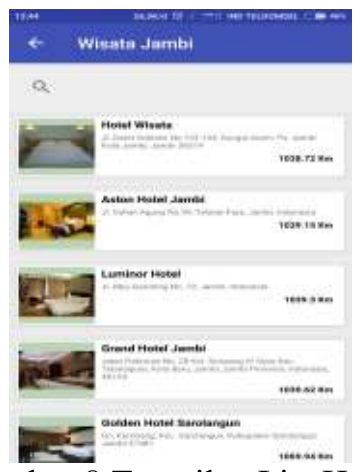

Gambar 8 Tampilan List Hotel

Gambar 8 merupakan Tampilan List Hotel dimana user dapat memilih hotel yang akan dituju.

a) Tampilan Lokasi Hotel

Tampilan Lokasi Hotel dapat dilihat pada gambar 9 sebagai berikut:

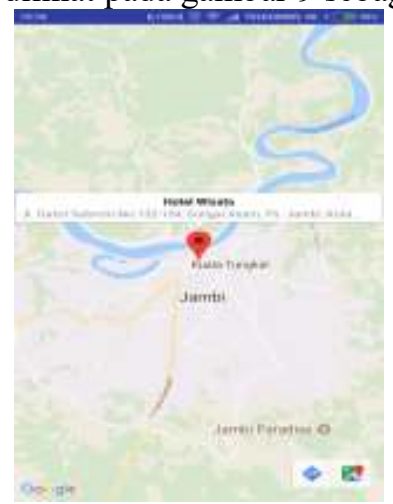

Gambar 9 Tampilan Lokasi Hotel

Gambar 9 merupakan Tampilan Lokasi Hotel yang dituju user, dari peta tersebut user dapat melihat rute mana yang harus tempuh, selain itu user juga dapat mengetahui waktu yang dibutuhkan untuk sampai ketujuan.

b) Admin

1. Halaman Login Admin

Halaman Login Admin dapat dilihat pada gambar 10 sebagai berikut:

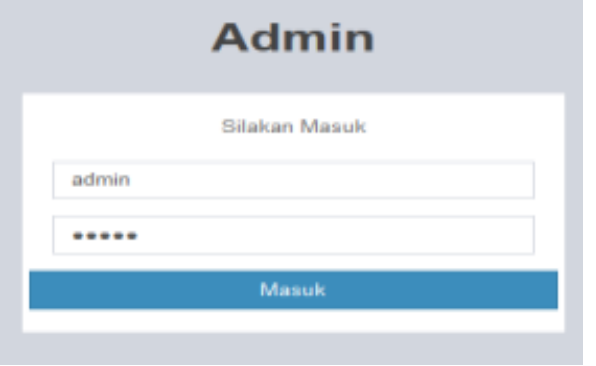

Gambar 10 Halaman Login Admin

Admin harus memasukkan username dan password lalu klik tombol masuk, jika username dan password benar maka sistem akan menampilkan halaman beranda admin. Jika username dan passwod salah maka admin tidak dapat masuk pada halaman beranda.

2. Halaman Utama pada $W e b$ Admin

Halaman Utama pada $W e b$ Admin dapat dilihat pada gambar 11 sebagai berikut : 


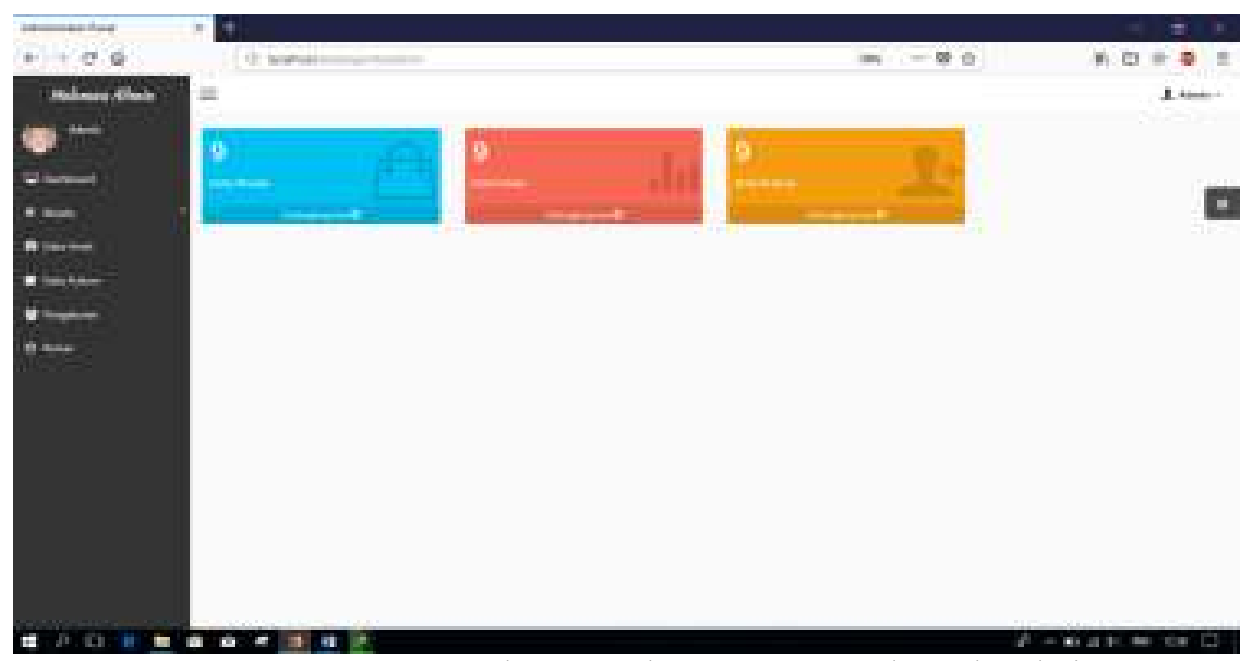

Gambar 11 Halaman Utama pada Web Admin

Apabila proses login sudah berhasil, maka sistem akan menampilkan halaman beranda admin, menu yang akan ditampikan pada beranda ada tiga yaitu menu mengelola data wisata, data hotel dan data kuliner. Selanjutnya admin klik menu data wisata maka akan tampil halaman data wisata seperti gambar 11 .

3. Halaman Data Wisata

Halaman Data Wisata dapat dilihat pada gambar 12 sebagai berikut:

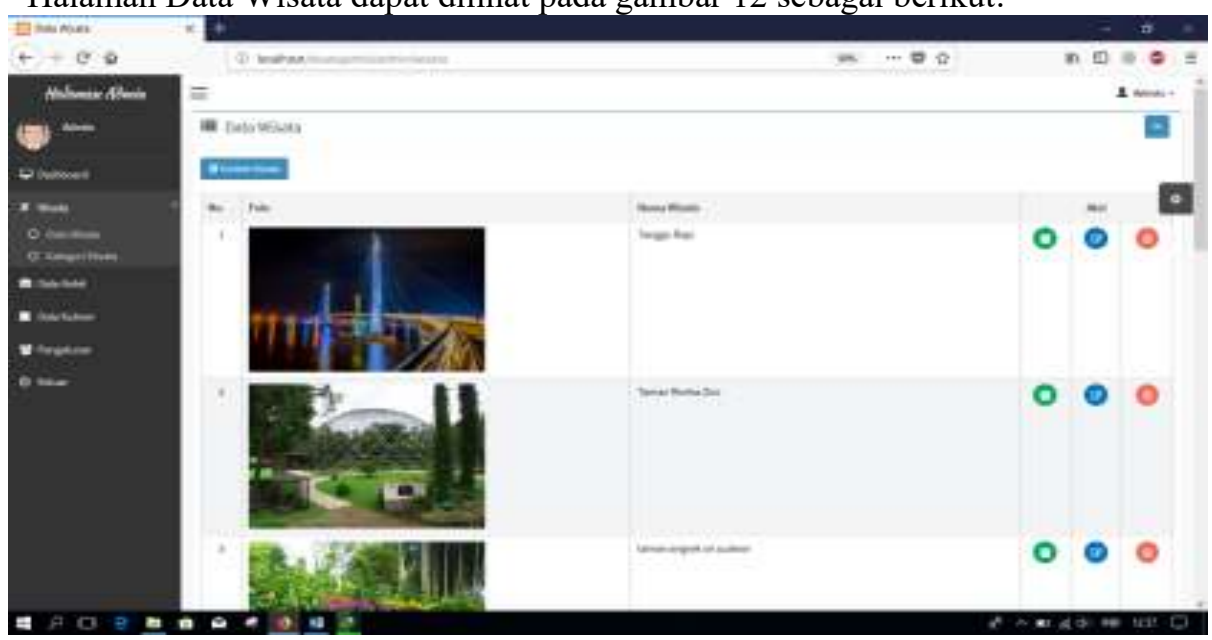

Gambar 12 Halaman Data Wisata

Setelah masuk pada halaman mengelola data wisata, admin dapat melihat data wisata secara detail dengan cara klik tombol detail maka akan muncul seperti gambar 12 admin juga dapat mengedit atau mengubah data wisata dengan cara klik tombol edit dan admin dapat menghapus data wisata dengan cara klik tombol hapus makan akan muncul kotak dialog "Yakin ingin menghapus data wisata ini ?" jika ingin menghapus klik "Ok" jika tidak ingin menghapus klik "Tidak" data wisata tidak terhapus. 


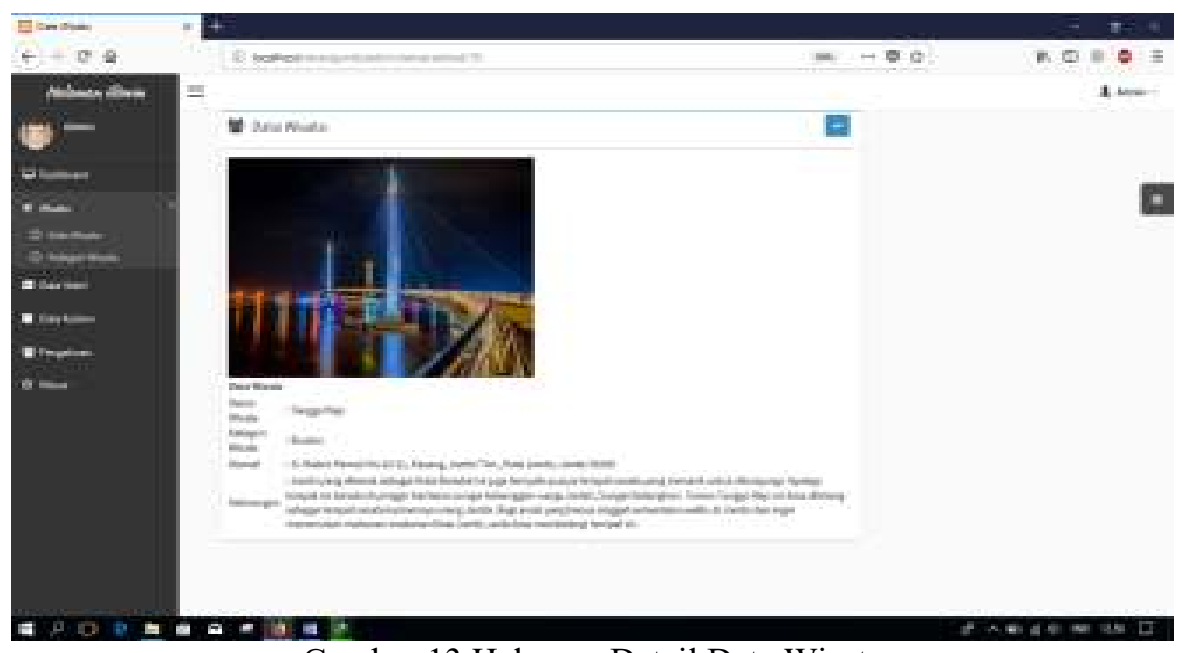

Gambar 13 Halaman Detail Data Wisata

Gambar 13 admin akan melihat detail data wisata dengan cara klik tombol detail warna hijau maka akan muncul halaman detail data wisata, sehingga admin dapat melihat data wisata dengan jelas.

4. Halaman Data Hotel

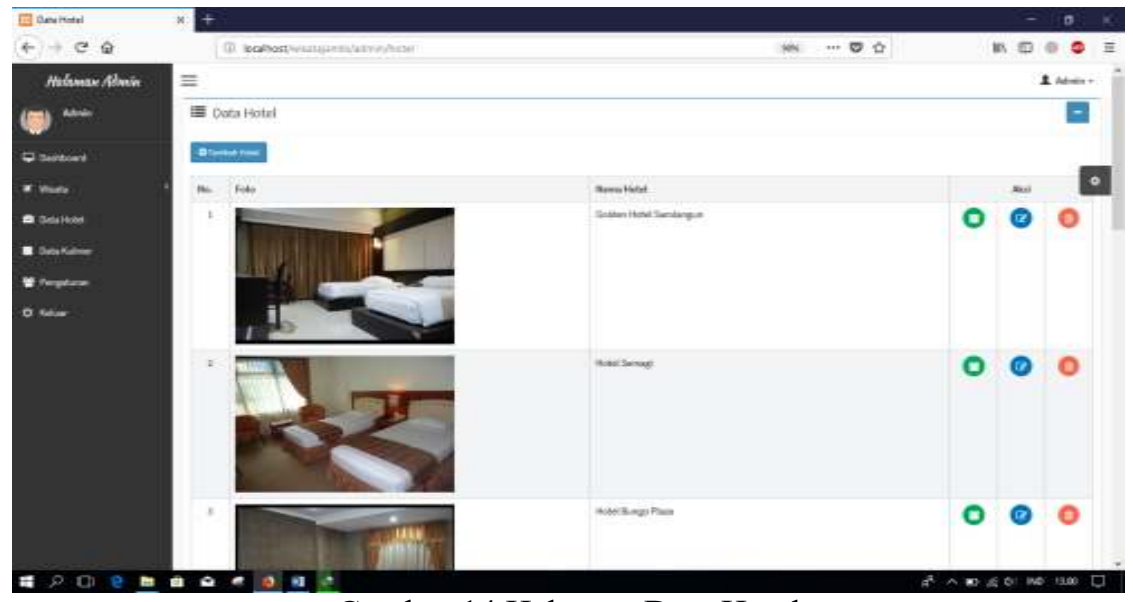

Gambar 14 Halaman Data Hotel

Selain data wisata menu yang kedua yaitu menu data hotel, admin dapat melihat data wisata secara detail dengan cara klik tombol detail maka akan muncul, admin juga dapat mengedit atau mengubah data hotel dengan cara klik tombol edit dan admin dapat menghapus data hotel dengan cara klik tombol hapus makan akan muncul kotak dialog "Yakin ingin menghapus data wisata ini ?" jika ingin menghapus klik "Ok" jika tidak ingin menghapus klik "Tidak" data hotel tidak terhapus. Halaman Detail Data Hotel dapat diihat pada gambar 15 sebagai berikut: 


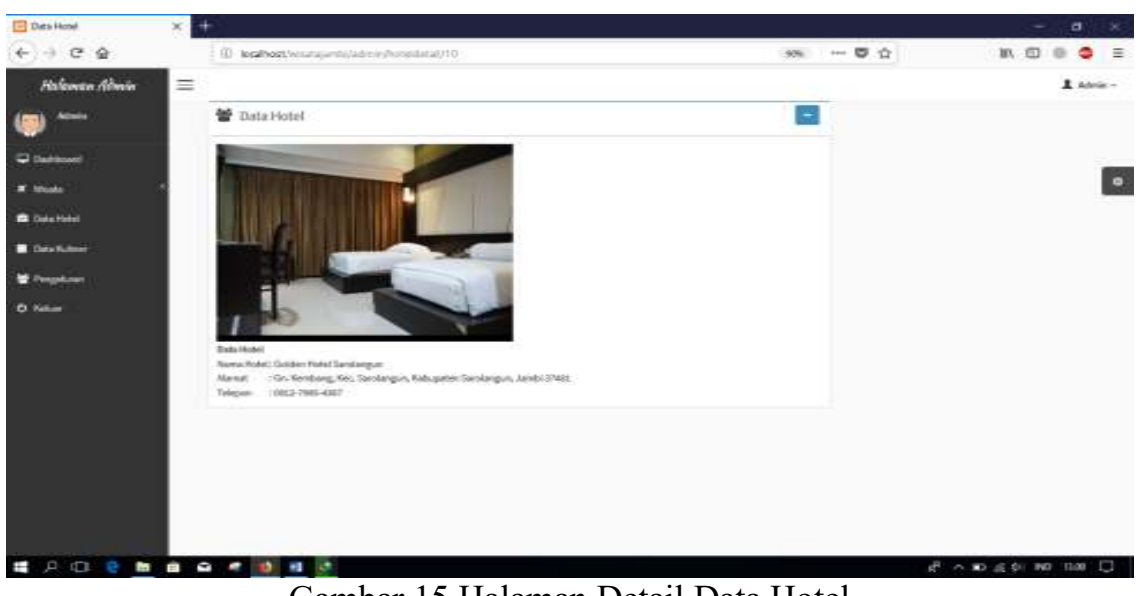

Gambar 15 Halaman Detail Data Hotel

Gambar 15 admin akan melihat detail data hotel dengan cara klik tombol detail warna hijau maka akan muncul halaman detail data hotel, sehingga admin dapat melihat data hotel dengan jelas.

5. Halaman Data Kuliner

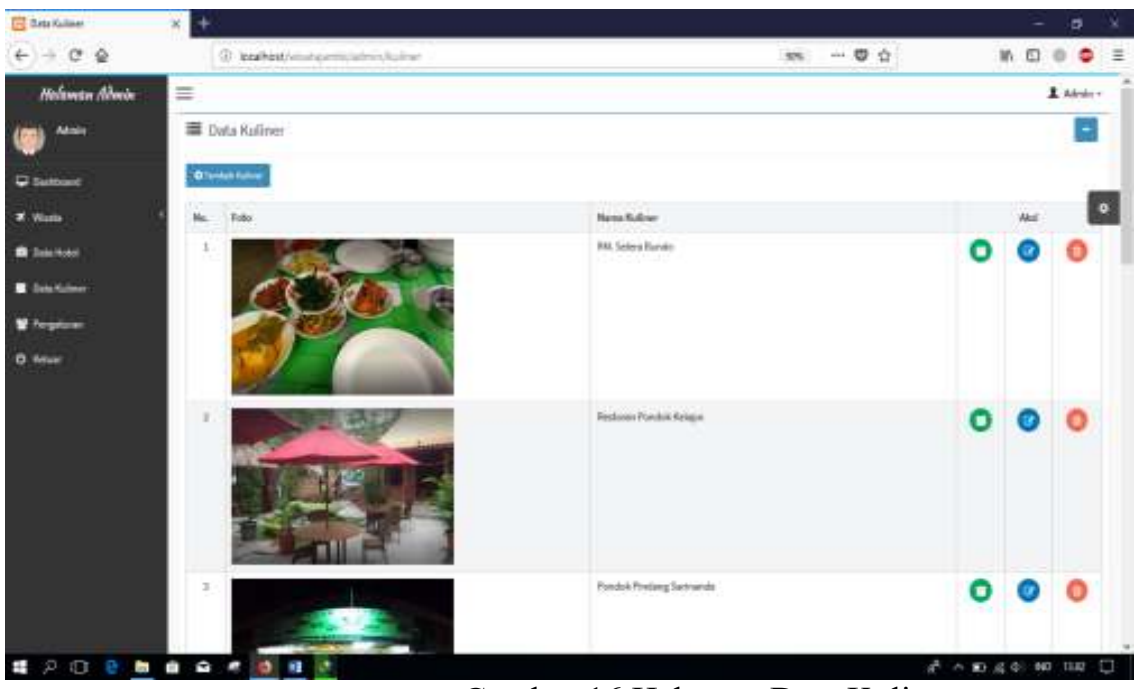

Gambar 16 Halaman Data Kuliner

Selanjutnya yaitu menu data Kuliner, admin dapat melihat data kuliner secara detail dengan cara klik tombol detail maka akan muncul, admin juga dapat mengedit atau mengubah data kiliner dengan cara klok tpmbol edit dan admin dapat menghapus data kuliner dengan cara klik tombol hapus makan akan muncul kotak dialog "Yakin ingin menghapus data wisata ini ?" jika ingin menghapus klik "Ok" jika tidak ingin menghapus klik "Tidak" data kuliner tidak terhapus. Halaman Detail Data Kuliner dapat dilihat pada gambar 17 sebagai berikut: 


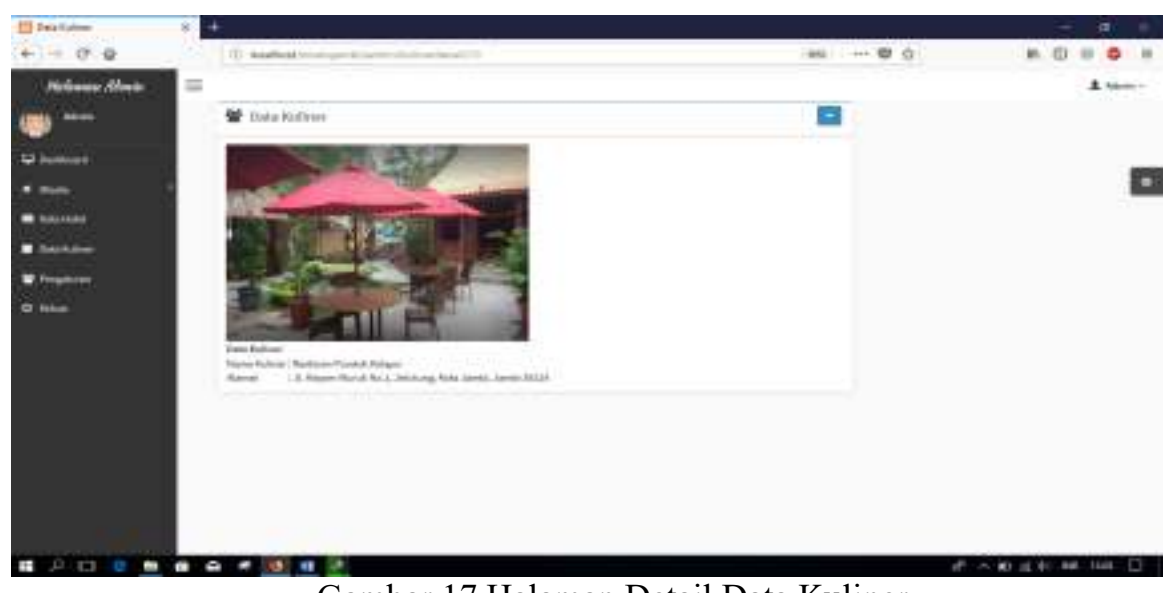

Gambar 17 Halaman Detail Data Kuliner

\section{KESIMPULAN}

Hasil perancangan Aplikasi Wisata Jambi dibuat menggunakan metode pengumpulan data yaitu dengan mengunakan metode wawancara, metode observasi dan metode pustaka. Alur sistem menggunakan Flowchart, UML (Unified Modeling Language) yang terdiri dari dari Usecase Diagram, Activity Diagram, Sequence Diagram, Class Diagram, dan Entity Relationship Diagram. Sedangkan untuk metode pengembangan menggunakan metode waterfall. Pengembangan sistem menggunakan bahasa pemrograman pendukung Android Studio Versi 3.0.1, PHP, Java dan MySQL sebagai pengolahan database. Sistem ini bisa melakukan pengolahan data wisata, data hotel dan data kuliner. Adanya Aplikasi Wisata Jambi ini membantu memberikan informasi wisata serta menampilkan lokasi wisata yang dituju. Dan tidak hanya memberikan informasi wisata saja tetapi juga dapat memberikan informasi hotel dan kuliner.

\section{SARAN}

Agar aplikasi sistem ini lebih sempurna diperlukan pengembangan lebih lanjut terutama dalam fasilitas-fasilitas didalam aplikasi sepeti menambahkan reservasi hotel dan sistem pembayaran hotel serta kuliner. Didalam sistem pembayaran tersebut wisatawan dapat melakukan pembayaran hotel dan kuliner melalui aplikasi sehingga akan lebih memudahkan wisatawan dalam melakukan proses pembayaran saat memesan hotel dan kuliner.

\section{DAFTAR PUSTAKA}

[2] Afrina, Mira, Ibrahim, Ali. 2016. Sistem Informasi Pariwisata Berbasis Android. Jurnal Sistem Informasi (JSI), Vol. 8, No. 2, Palembang.

[3] Arief, M. Rudianto. 2011. Pemrograman Web Dinamis Menggunakan PHP dan MySQL. Yogyakarta : Andi.

[4] Budiman, Herman., 2013, Buku Pintar Gedget Android untuk pemula, Jakarta, Lembar Langit Indonesia.

[5] Decoster. 2012. Pengertian Java Development Kit. http://library.binus.ac.id diakses pada 2 Oktober 2017.

[6] Efendi Rizal. 2015. Rancang Bangun Sistem Informasi Geografis Persebaran Lokasi Obyek Pariwisata Berbasis Web dan Mobile Android. Semarang

[7] Erizon, Edi., 2012, Booklet Wisata Jambi, Jambi. 
[8] Faualdi, Ali., 2013, Perancangan Dan Pembuatan Sistem Informasi Pariwisata Kebupaten Simeulue Berbasis Web. Aceh.

[9] Gozali, Andriyanto. 2015. Pembuatan Sistem Informasi Pariwisata Kota Samarinda Berbasis Web. Jurnal Ilmiah Mahasiswa Universiatas Surabaya, Vol.4 No.1 (2015). Surabaya.

[10] Hermawan Rudi. 2015. Perancangan Sistem Informasi Geografis Tempat Pariwisata Kabupaten Pacitan Berasis Web. IJNS-Indonesian Jpurnal on Networking and Securityaccepted paper-injs.org. Pacitan.

[11] Jogiyanto. 2005. Analisis dan Desain Sistem Informasi : Pendekatan Terstruktur Teori dan Praktek Aplikasi Bisnis. Yogyakarta : Andi.

[12] Kartika Imam Santoso, Muhamad Nur Rais. 2015. Sistem Informasi Geografis Daerah Pariwisata Berbasis Android dengan Global Posting System (GPS), Scientific Journal of Information, Vol. 2, No. 1, Temanggung.

[13] Kasman Dharma. 2012. Definisi Android. http://materipasti.blogspot.com/2016/09/pengertian-android.html. Diakses pada tanggal 20 Desember 2017.

[14] Kristanto. 2003. Konsep dan Perancangan Basis Data. Yogyakarta : Andi.

[15] Munawar. 2005. Pemodelan Visual dengan UML. Yogyakarta : Penerbit Graha Ilmu.

[16] Nursanti, Asri, Diah., 2016, Panduan Obyek Wisata Kabupaten Pacitan Berbasis Android, Surakarta.

[17] Pratama, Martha, 2016. Pariwisata dataran Tinggi Kerinci Provinsi Jambi, Jurnal Teknik PWK, Vol 5, No 1, Jambi

[18] Presman, Roger S. 2012. Rekayasa Perangkat Lunak - Buku Satu, Pendekatan Praktisi (Edisi 7). Yogyakarta : Andi.

[19] Presman. 2015. Definisi Tahapan Kelebihan dan Kekurangan Waterfall. http://www.pengetahuandan teknologi.com/2015/09/metode-waterfall-definisitahapan.html. Diakses pada tanggal 20 Desember 2017.

[20] Ragil Wukil. 2010. Pedoman Sosialisasi Prosedur Operasi Standar. Mitra Wacana Media. Jakarta.

[21] Safaat, Nazruddin. 2012. Android Pemrograman Aplikasi Mobile Smartphone dan Tablet $P C$ Berbasis Android . Bandung : Informatika Bandung.

[22] Sandi. 2012. Definisi Pengertian dan Fungsi XAMPP Lengkap. https://indoskripsi.com diakses pada 22 November 2017.

[23] Septian. 2012. Definisi Pengertian Sistem Informasi Pariwisata. https://Kasael.blogspot.com/2012/11/sistem-informasi-pariwisata-6542.html, diakses pada tanggal 20 Desember 2017.

[24] Sinaga, Supriyono. 2010. Potensi dan Pengembangan Objek Wisata Dikabupaten Tapanuli Tengah. Kertas Karya. Program DIII Pariwisata. Universitas Sumatra Utara.

[25] Sugoyono. 2013. Metode Penelitian Pendidikan Pendekatan Kuantitatif, Kualitatif, dan R\&D. Bandung : Alfabeta.

[26] Wijayanto, Nurhadiono., 2015, Aplikasi Mobile Lokasi Objek Wisata Kota Dan Kabupaten Tegal Berbasis Android, Semarang.

GO INFOTECH: JURNAL ILMIAH STMIK AUB Vol. 24, No. 2, Desember 2018 : 81 - 94 